\title{
Highly Skilled South Asian Migrant Women in Australia: Hidden Economic Assets
}

\author{
Najia Syed ${ }^{1}$, Cathy Banwell ${ }^{1} \&$ Tehzeeb Zulfiqar $^{1}$ \\ ${ }^{1}$ National Centre of Epidemiology and Population Health, The Research School of Population Health, College of \\ Health and Medicine, The Australian National University, Canberra, Australia \\ Correspondence: Najia Syed, National Centre of Epidemiology and Population Health, The Research School of \\ Population Health, College of Health and Medicine, The Australian National University, Canberra, Australia. Tel: \\ 612-61-049-521. E-mail: Najia.Syed@anu.edu.au
}

Received: August 22, 2020 Accepted: October 27, 2020 Online Published: October 30, 2020

doi:10.5539/gjhs.v12n12p130 URL: https://doi.org/10.5539/gjhs.v12n12p130

\begin{abstract}
Finding a balance between work and family life is challenging for many women, particularly migrant women living in Australia without family support. This study provides insights into their dilemmas, difficulties and strengths in terms of household responsibilities and employment pressures. Design: Qualitative, in-depth interviews were conducted with ten South Asian skilled mothers living in Canberra, Australia. Findings: Participants were positive about contributing to their family's income and gaining financial independence. However, as skilled migrant women, they struggled to use their work skills due to increased demands of domestic responsibilities. They often negotiated work and family life by seeking low-prospect careers. Conclusion: The socio-cultural factors faced by South Asian migrant women have a significant impact on their work-life balance. Deskilling, increased work pressures and lack of support may negatively impact their career aspirations and well-being. Flexible policies can help mitigate these barriers to help migrant women maintain a work-life balance.
\end{abstract}

Keywords: Highly skilled, South Asian migrant women, Work-life balance

\section{Background}

With more than one-quarter of its population comprising international migrants, the strength of Australian society lies in its rich cultural diversity (Australian Bureau of Statistics, 2019). Many skilled women, with professional qualifications, migrate to Australia with their spouses in the hope of better job opportunities and work prospects (Ahmad, 2001; Greenhaus \& Powell, 2006; Rajendran, Farquharson, \& Hewege, 2017; Rajendran, Ng, Sears, \& Ayub, 2020). While managing work and family are identified as stressful and challenging for all Australians (Pocock, 2003), social and cultural factors from the origin and host countries' cultures impact migrant workers differently (O’Dwyer \& Colic-Peisker, 2016; Syed, 2008; Turchick Hakak \& Al Ariss, 2013). Despite increased globalisation and a higher rate of skilled migration, the concept of work-life balance among skilled migrant woman is understudied. Little is known about the effects of underemployment and potential work-family conflict on migrant women's health. This paper explores this under-researched topic as it is vital to understand the experiences of the growing number of migrant women if they are to be successfully integrated into Australian society.

Skilled migration programs are designed to fulfil skill shortages in specific labour markets and to curtail the impact of lower fertility rates and ageing populations in those countries (Phan, Banerjee, Deacon, \& Taraky, 2015). Migration can create new opportunities for many people, but often migrant women bear the brunt of adapting to a new environment (Rajendran et al., 2017; Ressia, Strachan, \& Bailey, 2017; Shaffer, Harrison, Gilley, \& Luk, 2001). Australian migrant women have lower rates of employment compared to Australian-born women (Broderick, 2012; Fortin, 2005; Liebig, 2007; Sloan, 2012). Despite their academic credentials, skilled migrant women often have to reduce their working hours, work in low-skill occupations or compromise their careers and take more traditional gender roles as wives and mothers after immigration (Cooke, Zhang, \& Wang, 2013; Ho, 2006; Ressia et al., 2017). This results in underutilising the skills of a large group of workers in the Australian workforce (Hawthorne, 2015; Rajendran et al., 2020). Skilled women are migrating in increasing numbers. However, we understand little about these women's experiences and employment outcomes (Cooke et al., 2013; Kofman, 2014; Phan, Banerjee, Deacon, \& Taraky, 2015; Ressia et al., 2017), including how they progress professionally (Pio \& Essers, 2014). 
Migrant women's settlement is a complex process that should be considered in the context of their families (Kõu \& Bailey, 2017; Webb, 2015). Traditionally, South Asian families are tightly knit, with members often living as an extended family (Ballard, 2002; Kõu, Mulder, \& Bailey, 2017; Parekh, Singh, \& Vertovec, 2003). In their country of origin, childcare and housework are shared with older female family members, which enables working mothers to pursue their careers, but this support is interrupted by migration (Kõu et al., 2017). Cultural expectations about migrant women's domestic and caring roles may lead them to either compromise or downscale their careers when this support is not available. South Asian women fully expect to do most or all household work without much input from their partners, which is a major barrier to career advancement (Sharma, 2016). Hakim's theory of lifestyle preference $(2000,2003)$ postulates that modern women make individual choices concerning work and family commitments based on their personal preferences, suggesting that women may choose freely between paid employment and unpaid domestic work. In this study, we argue that the concept of choice or preference does not sufficiently explain women's experiences because it ignores the many socio-cultural and external factors which influence migrant women's work and family life.

Contrary to the government's claims that skilled migrants are achieving successful outcomes in the Australian labour force, women are struggling to find employment suited to their skills. Thompson, O'Dwyer and Chan called Australian skilled migrant women a "hidden asset" (2016, p. 16) and "trailing spouses" (2016, p. 13). The process of migration heightens the gender imbalance within migrant communities (O'Dwyer \& Colic-Peisker, 2016). Migrant women face multiple challenges after migration: navigating cultural norms, seeking appropriate employment and managing household responsibilities. In many cases, migrant women are disadvantaged in terms of getting equal job opportunities and updating their skills. As a result, their employment prospects decline and they are prone to downward occupational mobility (Hawthorne, 2011, 2015; Iredale, 2005; O'Dwyer \& ColicPeisker, 2016).

Previous studies have highlighted the challenges facing women migrants in Australia. Cooke, Zhang, \& Wang (2013), explored the various barriers affecting Chinese professional women's career advancement after migrating to Australia. Cooke et al. (2013) argued that these women face multiple challenges in the form of loss of human and social capital and discrimination within the workplace, which made them seek jobs at the lower skill and pay levels as compared to those jobs held before migration (O’Dwyer \& Colic-Peisker, 2016; Zorlu, 2016). In contrast to Australian-born women, migrant women face additional barriers entering the labour market, such as undervaluation of their overseas employment experience and lack of social networks (O'Dwyer \& Colic-Peisker, 2016; Rajendran et al., 2017; Ressia et al., 2017). Migrants from South Asia are the fastest growing communities in Australia (Australian Bureau of Statistics, 2019). Sharma (2016), in her research, found that South Asian migrant women in Australia are highly qualified than Australian-born women in similar economically active age-groups. She also reported that more than $50 \%$ of South Asian women who have migrated to Australia have little or no income of their own, particularly women from Pakistani and Bangladeshi descent. According to the latest labour force statistics (Australian Bureau of Statistics, 2016), 8\% of South Asian women with the highest educational attainment from India, Pakistan and Bangladesh, are not in the Australian workforce compared to only $3 \%$ of South Asian men from the same countries with similar qualifications. These figures illustrate that South Asian migrant women are economically more disadvantaged than migrant men. Women labour participation will only increase if their partners share the burden of household responsibilities equally (Sharma, 2016).

Increasingly, employment is recognised as a critical determinant of health, while unemployment is considered a risk factor for ill-health and poor well-being (Marmot, 2005; Reid, 2012). Work-family conflict is corrosive for the mental health of working partners, and initiatives used to relieve work-family conflict has shown to drastically improve the mental health of working parents (Cooklin et al., 2016). However, little is known about the risks of underemployment and potential work-family conflict on migrant women's health. It is, therefore, vital to understand the experiences of the growing number of migrant women if they are to be successfully integrated into Australian society. Our qualitative study aimed to explore migrant women's trade-offs between work, family and gender roles while balancing the demands of work and family life. Using in-depth interviews with South Asian migrant women, this study sought to answer the following questions:

- What are the cultural expectations from migrant women regarding their domestic and caring responsibilities?

- What are their career aspirations?

- How do these women maintain their work-life balance?

\section{Methodology}

\subsection{Study design}

A qualitative study design was adopted to obtain a rich description of subjective experience (Creswell \& Creswell, 
2017; Guba \& Lincoln, 1994) of migrant women's work-life balance and the meaning of social issues attributed to them.

\subsection{Recruitment and Sampling}

The study purposively recruited professionally qualified migrant women from Pakistan, India and Bangladesh residing in Canberra, with at least one school-going child, who were either currently working or had worked in Australia and were fluent in English. Migrant women were contacted through fliers written in English sent out by the first author's (NS) network of acquaintances. A snowball approach was used to reach more women who fulfilled the inclusion criteria (Kvale \& Brinkmann, 2009). The sample size was guided by the data saturation principle in which interviews were concluded when data saturation is reached, or when no new relevant information emerges from the interviews (Padgett, 2012).

\subsection{Data Collection}

All the interviews took place in Canberra between November 2018 and January 2019 at a location convenient for the participants. The interviews were conducted in English and lasted for an average of 45 minutes. NS used a topic guide for face-to-face, semi-structured interviews. The interviews provided in-depth information which enabled participants to raise issues which had not been anticipated (Gabriel, 1998). The participants were encouraged to use words or phrases in their native language. Prompts such as "Can you tell me about the reasons behind the migration?" were used to encourage the participants to share their stories. All interviews were audio-recorded after obtaining written consent. They were transcribed by NS and the data were anonymised through the use of pseudonyms.

\subsection{Data Management and Analysis}

NS conducted an inductive thematic analysis to identify, analyse and report patterns or themes within the data (Braun \& Clarke, 2013). Each interview transcript was read carefully. Codes were generated inductively from the data, keeping in mind the research questions, and applied to meaningful segments of the transcripts. Later, coded text segments were consolidated according to the potential themes and patterns in consultation with the second author.

\subsection{Ethical Considerations}

The research was conducted under the Australian National Health and National Health Medical Research Council (NHMRC) guidelines and with approval from the Australian National University Human Ethics Committee.

\section{Findings}

A total of 10 South Asian women aged 32-47 years participated in the research (Table 1). All the participants held a professional degree from their home country. Most participants had two or more children, had migrated through a partner visa and had been living in Australia for more than 10 years.

Four main themes emerged from these interviews: gendered division of labour, socio-cultural influences, financial independence and unintended health consequences. 
Table 1. Demographic Characteristics of South Asian Migrant Women

\begin{tabular}{|c|c|c|c|c|c|c|c|c|c|c|c|c|}
\hline No. & $\begin{array}{l}\text { Age } \\
\text { (Years) }\end{array}$ & Pseudonym & $\begin{array}{l}\text { Country } \\
\text { of Origin }\end{array}$ & Religion & $\begin{array}{l}\text { Years } \\
\text { In } \\
\text { Australia }\end{array}$ & Education & & $\begin{array}{l}\text { Employment } \\
\text { Status }\end{array}$ & $\begin{array}{l}\text { Number of } \\
\text { Children }\end{array}$ & $\begin{array}{l}\text { Profession \& Duration } \\
\text { of Work in Australia }\end{array}$ & $\begin{array}{l}\text { Profession \& } \\
\text { Duration of Work in } \\
\text { Country of Origin }\end{array}$ & $\begin{array}{l}\text { Household } \\
\text { Income }\end{array}$ \\
\hline 1 & 40 & Anushka & IND & Hindu & 14 & $\begin{array}{l}\text { Bachelor's } \\
\text { Science }\end{array}$ & in & $\begin{array}{l}\text { Part } \\
\text { time }\end{array}$ & 2 & $\begin{array}{l}\text { Medical Transcription, } \\
12 \text { years }\end{array}$ & $\begin{array}{l}\text { Medical Transcription, } \\
8 \text { years }\end{array}$ & $>\$ 100,000$ \\
\hline 2 & 39 & Simran & IND & Sikh & $13+$ & $\begin{array}{l}\text { Bachelor's } \\
\text { Electronics } \\
\text { Telecom }\end{array}$ & $\begin{array}{l}\text { in } \\
\&\end{array}$ & Full time & 2 & $\begin{array}{l}\text { I.T Professional, } \mathbf{1 0} \\
\text { years }\end{array}$ & $\begin{array}{l}\text { Web developer, 4-5 } \\
\text { years }\end{array}$ & $>\$ 100,000$ \\
\hline 3 & 37 & Sarah & PAK & Muslim & 13 & $\begin{array}{l}\text { Bachelor's } \\
\text { Dentistry }\end{array}$ & in & Part time & 2 & $\begin{array}{l}\text { Dental Assistant/ } \\
\text { Real estate, 5-6 years }\end{array}$ & Dental student, $\mathbf{5}$ years & $>\$ 100,000$ \\
\hline 4 & 40 & Zara & PAK & Muslim & 12 & $\begin{array}{l}\text { Bachelor's } \\
\text { Medicine } \\
\text { Surgery }\end{array}$ & $\begin{array}{l}\text { in } \\
\&\end{array}$ & Casual & 3 & Phlebotomist, 7 years & $\begin{array}{l}\text { Medical doctor, } 2 \\
\text { years }\end{array}$ & $>\$ 100,000$ \\
\hline 5 & 40 & Noori & PAK & Muslim & 11 & $\begin{array}{l}\text { Bachelor's } \\
\text { Pharmacy }\end{array}$ & in & Part time & 3 & $\begin{array}{l}\text { Childcare/Pharmacy } \\
\text { Assistant, } 5 \text { years }\end{array}$ & $\begin{array}{l}\text { Clinical Pharmacist, } 3 \\
\text { years }\end{array}$ & $<\$ 100,000$ \\
\hline 6 & 37 & Shewta & IND & Hindu & 10 & $\begin{array}{l}\text { Master's } \\
\text { International } \\
\text { Business }\end{array}$ & in & Full time & 2 & $\begin{array}{l}\text { Strategy Planning, } 9 \\
\text { years }\end{array}$ & $\begin{array}{l}\text { Operations } \\
\text { Manager, } 4 \text { years }\end{array}$ & $>\$ 100,000$ \\
\hline 7 & 39 & Shama & PAK & Muslim & 10 & $\begin{array}{l}\text { Bachelor's } \\
\text { Dentistry }\end{array}$ & in & Part time & 3 & $\begin{array}{lll}\begin{array}{l}\text { General } \\
\text { years }\end{array} & \text { Dentist, }>\mathbf{3} \\
\end{array}$ & $\begin{array}{lll}\begin{array}{l}\text { General Dentist, } \\
\text { years }\end{array} & \\
\end{array}$ & $>\$ 100,000$ \\
\hline 8 & 40 & Farhana & $\mathrm{BD}$ & Muslim & 10 & $\begin{array}{l}\text { Master's } \\
\text { Computer } \\
\text { Engineering }\end{array}$ & in & Full time & 2 & $\begin{array}{l}\begin{array}{l}\text { Project Manager, } \\
\text { years }\end{array} \\
0\end{array}$ & $\begin{array}{l}\text { I.T Project } \\
\text { Management, } 8 \text { years }\end{array}$ & $>\$ 100,000$ \\
\hline 9 & 32 & $\mathrm{Naz}$ & $\mathrm{BD}$ & Muslim & 8 & $\begin{array}{l}\text { Bachelor's } \\
\text { Medicine } \\
\text { Surgery }\end{array}$ & $\begin{array}{l}\text { in } \\
\&\end{array}$ & Full time & 1 & Admin Support, 2 years & $\begin{array}{l}\text { Medical Student, } \mathbf{5} \\
\text { years }\end{array}$ & $>\$ 100,000$ \\
\hline 10 & 47 & Nasrin & $\mathrm{BD}$ & Muslim & 3.5 & $\begin{array}{l}\text { Master's } \\
\text { Sociology }\end{array}$ & in & Part time & 2 & $\begin{array}{l}\text { Childcare Educator, } 3.5 \\
\text { years }\end{array}$ & $\begin{array}{l}\text { Senior Communication } \\
\text { Manager, } 4 \text { years }\end{array}$ & $\begin{array}{l}> \\
\$ 100,000\end{array}$ \\
\hline
\end{tabular}

$\mathrm{BD}=$ Bangladesh; IND=India, $\mathrm{PAK}=$ Pakistan. 


\subsection{Gendered Division of Labour}

Balancing career and family roles were the biggest challenge for all participants. They stated that their husbands had encouraged them to work and agreed to share household chores with them. However, they did not receive the level of support they needed. For example, husbands who supported their wives to work did not do additional household work, leaving women feeling exhausted. Zara, a phlebotomist, who has three children, explained it as follows:

When I come back home, I don't stop working... When the kids get sick, I am the only one who takes days off ... to look after the sick child, and it should go either way, but it does not in my case.

Many participants, particularly those with young children or elderly family members living with them, opted for flexible working hours due to the high cost of full-time day-care and their domestic responsibilities. This, in turn, reinforced their role as the primary caregiver with little help from husbands. Women felt that they could not be successful in their careers due to their excessive domestic and paid workloads. Shama, a part-time dentist, said:

In domestic chores, I get very little help from my husband ... I have got lots of complaints ... my husband just does not even think about it.

However, like some other women, she rationalised her contribution by saying:

I feel it's fair that I am contributing more in caring responsibilities because I do not feel pressured for earning like my husband.

\subsubsection{Traditional Gender Roles}

Participants spent a considerable number of hours in caring responsibilities, cleaning and preparing fresh meals. These activities are part of women's traditional role in their origin countries, but in Australia they performed them without help from other family women and paid domestic labour which was commonly available in their origin countries. Cooking is fundamental to their identities, and household responsibilities are part of being a good mother and a good wife (Bhandari \& Titzmann, 2017). Participant Zara feels primarily responsible for her growing children's dietary requirements, stating that, "Cooking is my job at home because if I don't cook, my kids will eat anything they find in the kitchen." Another participant Sarah, a part-time real estate agent, believed that the "way to our husband's heart is through their tummies." While reminiscing about living with her parents, Shewta, a full-time strategy planner, explained that:

In India, we were treated like princesses. Here all of that housework consumes so much time.

\subsection{Socio-Cultural Influences}

Based on their cultural backgrounds, many participants felt that it was their moral and cultural duty to look after their family. Simran, a full-time IT professional, lived with her mother-in-law, who dominated the household decisions. She found it hard to balance her household and work responsibilities:

We have a patriarchal society in India ... I was not expecting that my husband would help ... I used to feed the baby at night; still had to wake up at 5 in the morning to make food for in-laws, husband and myself before going to work.

There was a strong sense of responsibility to look after the well-being of partners. Anushka, a part-time medical transcriptionist, explained that:

In Indian culture, man is the breadwinner, bears the financial responsibility but at the same time it's a wife responsibility to ensure that he doesn't get stressed [and] can concentrate on work.

Husbands, generally, did not help with domestic chores and seemed oblivious to the complex pressures affecting their wives with paid work. Zara explained that:

... husbands come from a background where women look after the house, men only look after the financial aspects... Here I had that pressure to work and at the same time do the house chores... if sometimes I missed anything, he did not get happy.

Many participants felt guilty about building their careers. Some felt that their husbands undermined their jobs, as the participants often earned less than their husbands. Noori, a part-time pharmacy assistant, expressed her resentment for the lack of spousal support:

It's their "ehsaan" (favour) on us that they are letting us work. We are often told to leave work, if sometimes unable to fulfil our responsibilities... Husbands are the primary earners ... our pay is little compared to theirs, so I do more domestic chores to fill the gap ...

Noori compensated for her meagre pay by undertaking most of the domestic chores which seemed to her like a "motherhood penalty". Participants who downscaled their careers and had low-income jobs felt they had little power within their relationships. 
In contrast, some participants felt that in Australia people do not appreciate women's domestic work and encourage women to be in the paid workforce. For example, Simran recalled that her husband was urged by his peers to make her join the workforce. However, joining the workforce increased workload for women. They faced a conflicting set of socio-cultural norms and values between their origin country and Australia. Nasreen, a part-time childcare educator, observed that migrant women worked harder at home than non-migrant Australians due to their traditional cultural roles:

We take on a lot more responsibilities than locals. It's a huge difference... We are following our traditions inside the home... after 9 to 5 work we do things which we used to do back home (in origin countries).

\subsubsection{Building Husbands' Careers}

Participants in our study prioritised their husbands' careers over theirs and therefore their husbands enjoyed unhindered career growth. Many respondents felt that primary responsibility to earn money lies with their husbands, so they consciously chose to help build their husbands' careers first in order to avoid conflict. Shama believes that women work to sustain their career and family life, while husbands bear the pressure to earn, saying:

I do not have to worry about earning ... because it's my husband's job. He is responsible for making money ... I have this relaxation, and he doesn't.

Women ensured that their husbands do not face family-related career interruptions. Zara considered that building her husband's career is the main priority, stating:

My husband never has trouble because I am there to look after the kids, ... it should not be like this and he should equally share the caring responsibility. But ... I am happy that he is earning a good amount of money now.

Women discreetly put their family first and often made sacrifices to accommodate family commitments. The responsibilities that fall on them are both emotionally and physically draining. Exhaustive domestic work gave women little status while paid work was a sign of empowerment for study participants.

\subsection{Financial Independence}

Attaining financial independence was a key incentive to join the workforce for many participants. Prior to migration, most participants were working and were financially stable in their origin countries. After migrating to Australia, despite being highly skilled, participants experienced difficult accreditation processes and unequal job opportunities, and they struggled to get jobs according to their qualifications. Many women changed their professions or started working in less prestigious jobs after migrating to Australia. The cost of raising a family was a major concern for many and led them to join the paid workforce to maintain a comfortable standard of living.

Paid work gave them a sense of accomplishment as they used their skills and at the same time supplemented their household finances. Although many were not the primary breadwinners, they felt that their contribution was essential to maintain quality of life for their families. Shewta's work contributed to her family income and was useful for her intellectual stimulation:

To maintain my sanity, I need to do a job as I cannot stay at home 24/7... Kids' quality education, [and] family holidays are not possible in single income.

Some women like Shewta found building their skills gave them a sense of achievement while others were satisfied with contributing to household finances for a comfortable living.

\subsubsection{A Dual Income is Essential for Marital Harmony}

A dual income was considered essential for happy family life. Being in the paid workforce provided participants with a sense of security, recognition as a valued family member, higher self-esteem and economic liberty. Participants believed that their paid work increased their marital harmony also. Farhana, a full-time project manager, arrived in Australia as a single mother of a 4-year-old:

If you are financially independent, you have more confidence. You can raise your kids well ... You can have a healthy marriage ... you don't have fights over money.

Other participants noted a positive change in their husbands' attitude when they started working. Zara shared:

... working is good for relationships... when both share the financial responsibilities... My husband felt more pressured when I quit the job... if you want a happy family life you have to work ... you don't have a choice... I feel independent in my spending now.

Participants also felt valued and in control due to their ability to support their family in cases of monetary hardships. Shama commented:

I feel stronger that at least financially I'm not relying on someone ... if my family goes through a difficult time ... I will be able to support them. 
Participants suggested that financial independence provided them with overall stability and autonomy and changed family power dynamics. For some participants, work was a form of fulfilment and freedom, even if they experienced downward occupational mobility. Four women said they had downscaled their careers but still felt that employment had brought a meaningful change in their lives.

\subsubsection{Downscaled Careers}

Women saw the potential downscaling of their careers as a consequence of not having adequate Australian work experience. Participants were reluctant to work full time if there was no flexibility. For some, getting a part-time or flexible job and able to look after children is a win-win situation. Zara, a qualified medical doctor but working as a phlebotomist, said:

... because of the caring responsibilities and lack of support I had to change my career ... but I'm happy with what I'm doing.

These work-life negotiations were not gender-neutral. For participants, sacrificing their careers to be a "good mother-wife" was a culturally normative behaviour. While Pakistani and Bangladeshi women believed that men are the real breadwinners and women's role is primarily that of a caregiver, Indian participants felt this less intensely. The difference may be due to religious and cultural differences. Either Indian women had more work experience before marriage, or they had realised that power dynamics could only be negotiated through economic stability.

\subsection{Unintended Health Consequences}

Participants felt there were health consequences of living in a constantly demanding environment, both in the workplace and at home. They had stressful routines as they worked hard in their workplaces, performed domestic chores with little or no help, and were responsible for childcare and care of elderly family members. This impacted negatively on their mental health, and some of them were diagnosed with clinical depression. A few participants struggled in their workplace also, which exacerbated their mental stress:

I was not respected for my work ... lost my self-confidence... used to shiver in meetings ... had panic attacks ... spent 6 months on the bed ... sick for one and half year and nobody knew what was wrong with me.

A few participants were afraid of speaking about their health issues and concealed their health-related concerns due to the fear of losing their jobs or showing their weakness to others. Three participants said they suffered anxiety and depression, and the other three had high blood pressure, fatigue and chronic back pain. Participants claimed that they did not attempt to advance their careers due to health concerns and family commitments. Many participants did not have time to pursue the hobbies they had in their home countries. However, participants stated that they did not regret their sacrifices but were content to be able to play an active role in their family's progress. All study participants mentioned the pressure of keeping everyone happy and the desire to have a spotless house, cook good food and have obedient children.

\section{Discussion}

This qualitative study shows that skilled South Asian women struggle to balance work and family demands due to socio-cultural roles carried from their origin countries. These women faced various disadvantages in maintaining work-life balance, such as gender inequality, downscaled careers and the burden of household and caring responsibilities. Other studies have reported similar issues among migrant groups in Australia (Ho, 2006; Thompson et al., 2016; Webb, 2015). However, our research has highlighted the dilemmas for skilled South Asian women who enjoyed promising careers and financial independence in their home countries due to strong domestic support and after migration had to reset their career aspirations. More than half of the study participants reported poor health which they associated with their inability to reconcile work and family life. To have a more productive Australian labour market, employers must understand the unique circumstances of the skilled migrant women.

The gendered division of work was entrenched in their families which led to conflict between work and family demands. Increased women's workforce participation contributes to gender equality, but employment does not spare women from caring responsibilities - instead, the workload of women increases (Crompton, Lewis, \& Lyonette, 2007). Our study showed that the normative socio-cultural roles of migrant women are a barrier to establishing a work-life balance. All participants in our research struggled to be a homemaker and a paid worker and had to rearrange their work lives to meet their domestic demands.

Our findings also demonstrated how interwoven social, cultural and family dynamics influence migrant women's career choices in contrast to the simplistic "neo-traditionalist" theories which argue that it is a woman's "own choice" to adjust their employment after motherhood (Hakim, 2000, 2003). We found that migrant women were dependent on their spouses' approval for their career choices. Motherhood further exacerbated the inequality of traditional gender roles and resulted in the negotiation of their career goals.

Similar to previous studies, we also found that employment empowered women with economic freedom, 
confidence, bargaining power in the family affairs and equality in their marital relationships (Fincher, 1995; Fincher, Campbell, \& Webber, 1993; Kofman, 2000, 2014). Financial independence is the primary motivation behind paid work and a source of accomplishment among many participants, as it contributes to the growing family expenses.

Study participants considered flexible or part-time work a suitable option, although it resulted in changing their career paths. This finding echoes past research which suggested that skilled migrant women downscale their careers to maintain a balance between work and family (Munkejord, 2017; O’Dwyer \& Colic-Peisker, 2016). Work-family conflict appears to be a common determinant for job satisfaction (Greenhaus \& Beutell, 1985). Similarly, disputes in caregiving and employment responsibilities due to lack of domestic support have shown to delay career progression for women (Zhou, 2017). Although different life events may affect women's careers at different ages, young women with school-aged children are the most affected (Johnstone, Lucke, \& Lee, 2011).

The emotional and physical stress on migrant women is significant in Australia due to the lack of family support which many had in their home countries. Living in a pressured environment may have adverse effects on the health and work progress of women (Dinh, Strazdins, \& Welsh, 2017). Participants reported mental and physical health issues commonly found among those who have downscaled their careers, but few disclosed undertaken treatments for mental illnesses. Encouraging skilled migrant workers to seek mental health advice may result in higher productivity and better working conditions.

The present research affirmed previous research that showed different employment arrangements between migrant sub-groups, with fewer Pakistani women working full time compared to Indian women (Bhopal, 1998; Sharma, 2016). Although difficult to explain, it may be that Indian women have stabilised the balance of power through their economic contributions.

The women in our study were overworked, time-constrained and had no time for self-care. Participants' husbands were supportive of their wives paid work but provided little support in household chores. It was encouraging to note a shift in this pattern, and several participants were happy that their husbands offered more help compared to the rest of the men in their communities. This change of attitude in male partners is probably because of financial obligations and cultural hybridisation (Sav \& Harris, 2013; Sav, Harris, \& Sebar, 2013, 2014). While gender attitudes towards women in public and private spheres are changing, and husbands may have accepted that women can go out to work, they are still reluctant to change cultural practices at home.

This study highlighted how socioeconomic factors and the process of migration influence migrant women's career choices. Participants expressed their frustration with low-skilled or part-time work. Our findings revealed that individual participants have the skills, competence and passion for keeping demanding jobs, but they lack support and struggle to voice their concerns.

All participants claimed that their work-life experiences are more complicated than the average working woman in Australia. Our study showcases the unique dilemmas of women within a "capitalocentric" society (Gibson-Graham, 2006, p. 2) - a society obsessed with output production or that links autonomy or liberation with financial independence. South Asian women value their domestic labour differently or aspire to do both paid and unpaid work but are constrained by socio-cultural factors and the gendered division of labour.

\section{Contribution to the Literature and Future Policy Implications}

This study contributes to culturally specific knowledge about skilled South Asian women and suggests that migrant women experience considerable challenges in combining paid work and unpaid work. It uncovers a nuanced understanding of why skilled migrant women experience career interruptions. For a more productive Australian labour market, employers must understand the unique circumstances that skilled migrant women live. Current economic and social policies should address the growing concerns of migrant women highlighted in this research if Australia is to benefit fully from their education and training. Australian multicultural policy should incorporate culture-specific actions and solutions in facilitating an environment where migrants can effectively integrate. Future research should explore broader issues pertaining to their health, work opportunities and skill recognition.

\section{Strengths and Limitations}

In-depth interviews and an inductive qualitative methodology were useful to understand the work-life experiences of a diverse group of people. The background of the primary author (NS), a skilled South Asian migrant, was valuable in gaining a rapport with the participants. The study results warrant caution in generalisability due to small sample size, with study participants limited to only three South Asian countries living in Canberra, Australia. Snowball sampling was another limitation.

\section{Conclusion}

This paper reflects on the practical difficulties of balancing work and family life faced by skilled South Asian 
women. Skilled migrants often face gender discrimination and have the dual burden of managing paid employment alongside domestic responsibilities, affecting their career aspirations. The pressure of being a good wife and mother and prioritising family over career is enormous. South Asian women show considerable commitment to traditional roles and value domestic work differently from non-immigrant Australian women: their motherhood responsibilities and the stability of their marriage are their main priorities while career comes afterwards. Both social and individual characteristics of women influence the empowerment of female migrants. The concept of "male breadwinner" and "female caregiver" is prevalent in these communities, and male power is dominant in decision-making. The demands of the caregiving role are irreconcilable, which they negotiate by undertaking a less demanding job. Excessive workload and subsequent stresses produce negative health impacts which need to be further researched. These women considered themselves to be the strength of the family and are the right "better halves" of their spouses.

\section{Acknowledgements}

We are grateful to the study participants for sharing their precious stories.

\section{Competing Interests Statement}

The authors declare that there are no competing or potential conflicts of interest.

\section{References}

Ahmad, F. (2001). Modern traditions? British Muslim women and academic achievement. Gender and Education, 13(2), 137-152. https://doi.org/10.1080/09540250120051169

Australian Bureau of Statistics. (2019, 2 April 2019). Migration, Australia, 2016-17 cat. no. 3412.0. Retrieved from https://www.abs.gov.au/AUSSTATS/abs@.nsf/allprimarymainfeatures/D55E16D6BF20AA7CCA2583D00 016ED30?opendocument

Australian Bureau of Statistics. (2016). BPLP Country of birth of person, HEAP Level of highest educational attainment and SEXP Sex by LFSP Labour force status (hierarchical) by CITP Australian citizenship [TableBuilder]. Retrieved from https://tablebuilder.abs.gov.au/

Ballard, R. (2002). The South Asian Presence in Britain and its Transnational Connections. In B. Parekh, G. Singh, \& S. Vertovec (Eds.), Culture and Economy in the Indian Diaspora. London: Routledge.

Bhandari, P., \& Titzmann, F.-M. (2017). Introduction. Family Realities in South Asia: Adaptations and Resilience. South Asia Multidisciplinary Academic Journal, (16). https://doi.org/10.4000/samaj.4365

Bhopal, K. (1998). How Gender and Ethnicity Intersect: The Significance of Education, Employment and Marital Status. Sociological Research Online, 3(3), 29-39. https://doi.org/10.5153/sro.146

Braun, V., \& Clarke, V. (2013). Successful Qualitative Research: A Practical Guide for Beginners. Sage.

Broderick, E. (2012). Women in the Workforce. Australian Economic Review, 45(2), 204-210. https://doi.org/10.1111/j.1467-8462.2012.00682.x

Cooke, F. L., Zhang, J., \& Wang, J. (2013). Chinese professional immigrants in Australia: A gendered pattern in (re) building their careers. The International Journal of Human Resource Management, 24(13), 2628-2645. https://doi.org/10.1080/09585192.2012.750615

Cooklin, A., Dinh, H., Strazdins, L., Westrupp, E., Leach, L., \& Nicholson, J. M. (2016). Change and stability in work-family conflict and mothers' and fathers' mental health: Longitudinal evidence from an Australian cohort. Social Science \& Medicine, 155, 24-34. https://doi.org/10.1016/j.socscimed.2016.02.036

Creswell, J. W., \& Creswell, J. D. (2017). Research design: Qualitative, quantitative, and mixed methods approaches. Sage publications.

Crompton, R., Lewis, S., \& Lyonette, C. (2007). Introduction: the unravelling of the 'male breadwinner'model-and some of its consequences. In R. Crompton, S. Lewis, \& C. Lyonette (Eds.), Women, men, work and family in Europe (pp. 1-16). Springer. https://doi.org/10.1057/9780230800830_1

Dinh, H., Strazdins, L., \& Welsh, J. (2017). Hour-glass ceilings: Work-hour thresholds, gendered health inequities. Social Science \& Medicine, 176, 42-51. https://doi.org/10.1016/j.socscimed.2017.01.024

Fincher, R. (1995). Women, Immigration and the State: Issues of Difference and Social Justice. In A. Edwards \& S. Magarey (Eds.), Women in a Restructuring Australia: Work and Welfare. Sydney, Australia: Allen and Unwin.

Fincher, R., Campbell, I., \& Webber, M. (1993). Multiculturalism, settlement, and migrants' income and employment strategies. In G. L. Clark, D. K. Forbes, \& R. Francis (Eds.), Multiculturalism, difference and postmodernism (pp. 103-125). Melbourne, Australia: Longman Cheshire. 
Fortin, N. M. (2005). Gender role attitudes and the labour-market outcomes of women across OECD countries. Oxford Review of Economic Policy, 21(3), 416-438. https://doi.org/10.1093/oxrep/gri024

Gabriel, Y. (1998). The use of stories. In G., Symon, \& C., Cassell (Eds.), Qualitative Methods and Analysis in Organizational Research: A practical guide. London: Sage.

Gibson-Graham, J. K. (2006). A Postcapitalist Politics. University of Minnesota Press.

Greenhaus, J. H., \& Beutell, N. J. (1985). Sources of conflict between work and family roles. Academy of management review, 10(1), 76-88. https://doi.org/10.5465/amr.1985.4277352

Greenhaus, J. H., \& Powell, G. N. (2006). When work and family are allies: A theory of work-family enrichment. Academy of management review, 31(1), 72-92. https://doi.org/10.5465/amr.2006.19379625

Guba, E. G., \& Lincoln, Y. S. (1994). Competing paradigms in qualitative research. In N. K. Denzin \& Y. S. Lincoln (Eds.), Handbook of qualitative research (pp. 105-117): Sage.

Hakim, C. (2000). Work-Lifestyle Choices in the 21st Century: Preference Theory. OUP Oxford.

Hakim, C. (2003). A New Approach to Explaining Fertility Patterns: Preference Theory. Population and Development Review, 29(3), 349-374. https://doi.org/10.1111/j.1728-4457.2003.00349.x

Hawthorne, L. (2011). Competing for Skills: Migration Policies and Trends in New Zealand and Australia: Full Report. Wellington, New Zealand: Department of Labour, New Zealand. Retrieved from https://www.homeaffairs.gov.au/research-and-stats/files/migration-policies-trends-fullreport.pdf

Hawthorne, L. (2015). The impact of skilled migration on foreign qualification recognition reform in Australia. Canadian Public Policy, 41(Supplement 1), S173-S187. https://doi.org/10.3138/cpp.2015-027

Ho, C. (2006). Migration as Feminisation? Chinese Women's Experiences of Work and Family in Australia. Journal of Ethnic and Migration Studies, 32(3), 497-514. https://doi.org/10.1080/13691830600555053

Iredale, R. (2005). Gender, immigration policies and accreditation: valuing the skills of professional women migrants. Geoforum, 36(2), 155-166. https://doi.org/10.1016/j.geoforum.2004.04.002

Johnstone, M., Lucke, J., \& Lee, C. (2011). Influences of Marriage, Motherhood, and Other Life Events on Australian Women's Employment Aspirations. Psychology of Women Quarterly, 35(2), 267-281. https://doi.org/10.1177/0361684310388502

Kofman, E. (2000). The invisibility of skilled female migrants and gender relations in studies of skilled migration in Europe. International Journal of Population Geography, 6(1), 45-59. https://doi.org/10.1002/(SICI)1099-1220(200001/02)6:1<45::AID-IJPG169>3.0.CO;2-B

Kofman, E. (2014). Towards a gendered evaluation of (highly) skilled immigration policies in Europe. International Migration, 52(3), 116-128. https://doi.org/10.1111/imig.12121

Kõu, A., \& Bailey, A. (2017). 'Some people expect women should always be dependent': Indian women's experiences as highly skilled migrants. Geoforum, 85, 178-186. https://doi.org/10.1016/j.geoforum.2017.07.025

Kõu, A., Mulder, C. H., \& Bailey, A. (2017). 'For the sake of the family and future': the linked lives of highly skilled Indian migrants. Journal of Ethnic and Migration Studies, 43(16), 2788-2805. https://doi.org/10.1080/1369183X.2017.1314608

Kvale, S., \& Brinkmann, S. (2009). Interviews: Learning the craft of qualitative research interviewing. sage.

Liebig, T. (2007). The Labour Market Integration of Immigrants in Australia. Retrieved from Paris: https://www.oecd-ilibrary.org/content/paper/235260166224

Marmot, M. (2005). Social determinants of health inequalities. The lancet, 365(9464), 1099-1104. https://doi.org/10.1016/S0140-6736(05)74234-3

Munkejord, M. C. (2017). His or her work-life balance? Experiences of self-employed immigrant parents. Work, Employment and Society, 31(4), 624-639. https://doi.org/10.1177/0950017016667041

O’Dwyer, M., \& Colic-Peisker, V. (2016). Facilitating the professional transition of migrants in Australia: does gender matter? Australian Journal of Social Issues, 51(1), 47-66. https://doi.org/10.1002/j.1839-4655.2016.tb00364.x

Padgett, D. K. (2012). Qualitative and mixed methods in public health. Thousand Oaks, CA: Sage publications. https://doi.org/10.4135/9781483384511

Parekh, B., Singh, G., \& Vertovec, S. (2003). Culture and economy in the Indian diaspora. London, New York: Routledge. https://doi.org/10.4324/9780203398296

Phan, M. B., Banerjee, R., Deacon, L., \& Taraky, H. (2015). Family dynamics and the integration of professional 
immigrants in Canada. Journal of Ethnic and Migration Studies, 41(13), 2061-2080. https://doi.org/10.1080/1369183X.2015.1045461

Pio, E., \& Essers, C. (2014). Professional migrant women decentring otherness: A transnational perspective. British Journal of Management, 25(2), 252-265. https://doi.org/10.1111/1467-8551.12003

Pocock, B. (2003). The work/life collision: What work is doing to Australians and what to do about it. Sydney, Australia: Federation Press.

Rajendran, D., Farquharson, K., \& Hewege, C. (2017). Workplace integration: the lived experiences of highly skilled migrants in Australia. Equality, Diversity and Inclusion: An International Journal, 36(5), 437-456. https://doi.org/10.1108/EDI-11-2016-0094

Rajendran, D., Ng, E. S., Sears, G., \& Ayub, N. (2020). Determinants of migrant career success: A study of recent skilled migrants in Australia. International Migration, 58(2), 30-51. https://doi.org/10.1111/imig.12586

Reid, A. (2012). Under-use of migrants' employment skills linked to poorer mental health. Australian and New Zealand Journal of Public Health, 36(2), 120-125. https://doi.org/10.1111/j.1753-6405.2012.00842.x

Ressia, S., Strachan, G., \& Bailey, J. (2017). Gender and migration: The experiences of skilled professional women. In K. Broadbent, G. Strachan, \& G. Healy (Eds.), Gender and the Professions (pp. 105-116). New York: Routledge. https://doi.org/10.4324/9781315563954-7

Sav, A., \& Harris, N. (2013). Work-life conflict in Australian Muslims: is gender important? Gender in Management: An International Journal, 28(8), 486-504. https://doi.org/10.1108/GM-01-2013-0013

Sav, A., Harris, N., \& Sebar, B. (2013). Work-life conflict and facilitation among Australian Muslim men. Equality, Diversity and Inclusion: An International Journal, 32(7), 671-687. https://doi.org/10.1108/EDI-07-2012-0058

Sav, A., Harris, N., \& Sebar, B. (2014). Australian Muslim men balancing work, family and religion: A positive look at a negative issue. Personnel Review, 43(1). https://doi.org/10.1108/PR-07-2012-0130

Shaffer, M. A., Harrison, D. A., Gilley, K. M., \& Luk, D. M. (2001). Struggling for balance amid turbulence on international assignments: work-family conflict, support and commitment. Journal of Management, 27(1), 99-121. https://doi.org/10.1177/014920630102700106

Sharma, N. (2016). Born to migrate: South Asian Women in Sydney and the convergence of marriage, migration and maternity in shaping their participation in the paid workforce. ( $\mathrm{PhD}$ Dissertation, Faculty of Arts Macquarie University, Sydney, Australia). Retrieved from https://www.researchonline.mq.edu.au/vital/access/services/Download/mq:57564/SOURCE1?view=true

Sloan, J. (2012). How Women Are Faring in the Australian Labour Market. Australian Economic Review, 45(2), 202-203. https://doi.org/10.1111/j.1467-8462.2012.00684.x

Syed, J. (2008). Employment prospects for skilled migrants: A relational perspective. Human Resource Management Review, 18(1), 28-45. https://doi.org/10.1016/j.hrmr.2007.12.001

Thompson, L., O’Dwyer, M., \& Chan, A. (2016). Hidden Assets: Partner Migration, skilled women and the Australian workforce. Retrieved from https://www.ames.net.au/-/media/files/research/ames-australiahidden-assets_partner-migration.pdf

Turchick Hakak, L., \& Al Ariss, A. (2013). Vulnerable work and international migrants: a relational human resource management perspective. The International Journal of Human Resource Management, 24(22), 4116-4131. https://doi.org/10.1080/09585192.2013.845427

Webb, S. (2015). The feminisation of migration and the migrants VET policy neglects: the case of skilled women secondary migrants in Australia. Journal of Vocational Education \& Training, 67(1), 26-46. https://doi.org/10.1080/13636820.2014.922117

Zhou, M. (2017). Motherhood, Employment, and the Dynamics of Women's Gender Attitudes. Gender \& Society, 31(6), 751-776. https://doi.org/10.1177/0891243217732320

Zorlu, A. (2016). Immigrants' occupational Mobility-Down and back up again. IZA World of Labor, 2016(290). https://doi.org/10.15185/izawol.290

\section{Copyrights}

Copyright for this article is retained by the author(s), with first publication rights granted to the journal.

This is an open-access article distributed under the terms and conditions of the Creative Commons Attribution license (http://creativecommons.org/licenses/by/4.0/). 